\title{
Regulation of heme biosynthesis and transport in metazoa
}

\author{
SUN FengXiu, CHENG YongJiao \& CHEN CaiYong* \\ College of Life Sciences and Innovation Center for Cell Signaling Network, Zhejiang University, Hangzhou 310058, China
}

Received March 4, 2015; accepted April 22, 2015; published online July 23, 2015

\begin{abstract}
Heme is an iron-containing tetrapyrrole that plays a critical role in regulating a variety of biological processes including oxygen and electron transport, gas sensing, signal transduction, biological clock, and microRNA processing. Most metazoan cells synthesize heme via a conserved pathway comprised of eight enzyme-catalyzed reactions. Heme can also be acquired from food or extracellular environment. Cellular heme homeostasis is maintained through the coordinated regulation of synthesis, transport, and degradation. This review presents the current knowledge of the synthesis and transport of heme in metazoans and highlights recent advances in the regulation of these pathways.
\end{abstract}

heme, iron, synthesis, transport, regulation

Citation: $\quad$ Sun FX, Cheng YJ, Chen CY. Regulation of heme biosynthesis and transport in metazoa. Sci China Life Sci, 2015, 58: 757-764 doi: $10.1007 / \mathrm{s} 11427-015-4885-5$

Heme is an iron-containing tetrapyrrole that serves as a critical cofactor for numerous proteins. Globins and cytochromes require heme for their biological functions $[1,2]$. Heme is also the activity center of such enzymes as catalases, myeloperoxidases, thyroperoxidases, lactoperoxidases, cytochrome P450s, inducible nitric oxide synthases (iNOS), and soluble guanylate cyclases (sGC) [1,2].

Besides serving as a cofactor, heme is an essential regulator of several cellular processes. Heme can bind and regulate the transcriptional factors BACH1, Rev-erbs, CLOCK, neuronal PAS domain-containing protein 2 (NPAS2), and $\mathrm{P} 53$. BACH1 is a transcriptional repressor. Binding of heme relieves the transcriptional repression and up-regulates downstream genes, which are involved in hematopoiesis, macrophage development, and antioxidation [3-6]. Heme also regulates the circadian rhythm by physically interacting with the nuclear receptors Rev-erb $\alpha$ and $\beta$, CLOCK, and NPAS2 [7-10]. Additionally, the activity of tumor suppressor protein P53 is regulated by heme availability [11]. Heme inhibits the interaction between P53 and its target DNA

*Corresponding author (email: chency@zju.edu.cn) element and facilitates the nuclear export and proteasomal degradation of P53 [11]. Heme is also required for the proper binding of the microprocessor subunit DGCR8 to primary microRNA transcripts (pri-miRNAs), and thus plays a critical role in the processing of pri-miRNAs [12-14].

Given the important biological role of heme in diverse cellular pathways, either insufficient or excess heme would have detrimental effects on cell metabolism and function. Further, free heme is a cytotoxic compound due to its intrinsic peroxidase activity. Thus, cells have developed exquisite mechanisms to regulate heme metabolism in order to maintain its homeostasis. This review presents the current knowledge of heme synthesis and trafficking in metazoans, and highlights recent advances in the regulation of these pathways. The regulation of heme degradation has been reviewed recently $[15,16]$ and is not discussed here.

\section{Regulation of heme biosynthesis}

\subsection{Uptake of iron for heme synthesis}

In most metazoan species, heme is synthesized via an eight-step pathway from the substrates ferrous iron, glycine, 
and succinyl-CoA (Figure 1). Most cells, especially developing erythrocytes, take up iron through transferrin cycle $[17,18]$. Transferrin receptor (TFR) on the cell surface interacts with di-ferric transferrin, followed by clathrinmediated internalization into early endosomes. During the maturation of endosomes, the associated iron is released. The rest of transferrin complex is recycled to the cell surface, where TFR and transferrin dissociate.

Regulatory molecules exist to ensure the unidirectional movement of the transferrin complex. Three studies unanimously reported that the phosphatidylinositol binding clathrin assembly protein (PICALM) plays an essential role in TFR endocytosis [19-21]. Picalm-deficient mice developed severe anemia, which is due to impaired uptake of iron in erythroid precursors. Further cell biological evidences suggest that PICALM facilitates the maturation of clathrin coat and the endocytosis of transferrin complex. Another trafficking protein required for the transferrin cycle is sorting nexin 3 (SNX3) [22]. SNX3 is highly expressed in the hematopoietic tissues of mice and zebrafish. Knockdown of snx3 in zebrafish embryos caused profound anemia, a phenotype that can be rescued by supplementing non-transferrin bound iron. Snx3-deficient erythroid cells had accumulation of transferrin complex within early endosomes, indi-

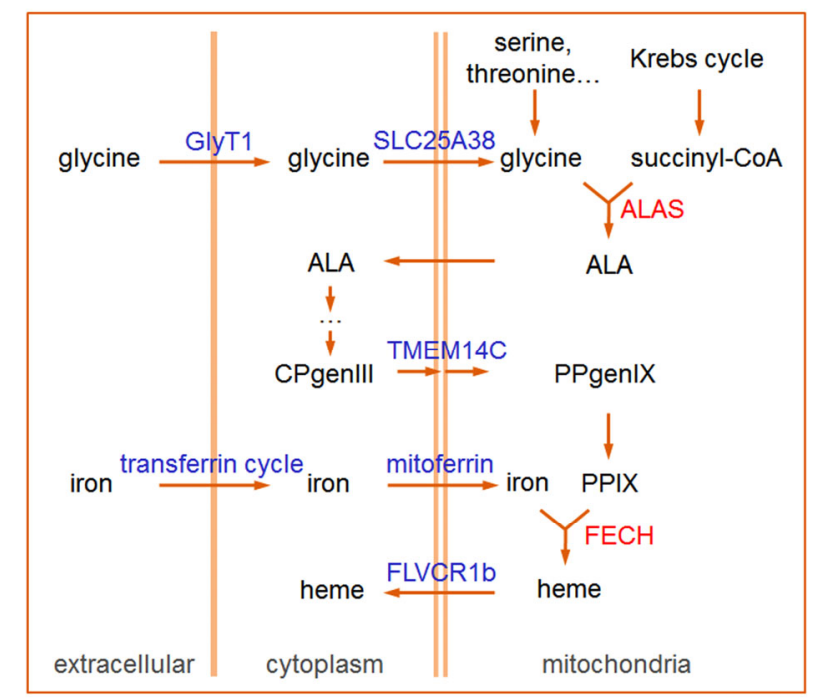

Figure 1 Regulation of heme synthesis in animals. Heme is synthesized via a conserved pathway comprised of eight enzyme-catalyzed reactions. Aminolevulinic acid synthase (ALAS) and ferrochelatase (FECH), the first and the last enzymes in the pathway, are regulated by the oxygen level and cellular iron status. Iron is imported into cells by the transferrin cycle, a process that is regulated by phosphatidylinositol binding clathrin assembly protein (PICALM), sorting nexin 3 (SNX3), and exocyst complex component 6 (SEC15L1). Mitoferrin mediates iron import into mitochondria. Glycine may be imported by glycine transporter 1 (GLYT1) and solute carrier family 25 member 38 (SLC25A38) or be generated within the mitochondria, and succinyl-CoA is provided by the Krebs cycle. Transmembrane protein 14C (TMEM14C) may translocate protoporphyrinogen IX (PPgenIX) across the inner mitochondrial membrane. The Feline Leukemia Virus subgroup $\mathrm{C}$ receptor $1 \mathrm{~b}$ (FLVCR1b) may transport heme out of mitochondria. cating impaired trafficking from early to recycling endosomes. Once reaching recycling endosomes, the transferrin complex requires the exocyst complex component SEC15L1 for returning to the cell surface $[23,24]$.

The net outcome of transferrin cycle is the translocation of iron from the blood circulation to endosomes. How does the imported iron move out of the endosomes and get into the mitochondria for heme synthesis? First, six-transmembrane epithelial antigen of the prostate member 3 (STEAP3) and related proteins reduce the ferric iron to ferrous iron $[25,26]$. Second, the ferrous iron is exported out of the endosomes. The divalent metal transporter DMT1 is known to translocate iron across the endosomal membranes [27]. The cation channel protein mucolipin 1 was also reported to be an iron channel in endolysosomes [28]. However, the primary function of mucolipin 1 is likely to transport calcium [29]. Third, following endosomal release, iron is transported to the mitochondria. Cytosolic iron chaperones, such as poly (rC) binding protein 1 (PCBP1) and PCBP2, deliver iron to the iron storage protein ferritin and cytoplasmic iron-containing proteins [30-32]. The specific chaperone that mediates iron transport from endosomes to the mitochondria has yet to be identified. Next, iron is imported into the mitochondria by mitoferrins [33]. Mitoferrin 1 is highly expressed in vertebrate hematopoietic tissues and plays a primary role in supplying iron for heme synthesis in erythroid cells [33]. Its ubiquitously expressed paralog, mitoferrin 2, may be responsible for mitochondrial iron import in non-erythroid cells [34].

\subsection{Supply of succinyl-CoA and glycine for heme syn- thesis}

The first and rate-limiting reaction in heme biosynthesis pathway is the condensation of succinyl-CoA and glycine to form $\delta$-aminolevulinic acid (ALA) (Figure 1). Succinyl-CoA is derived from the Krebs cycle (also called citric acid cycle). Over 50 years ago, it was proposed that the production of succinyl-CoA could be an important factor regulating heme production $[35,36]$. To date, however, it is still unclear whether succinyl-CoA is a limiting factor during heme synthesis and whether the rate of succinyl-CoA formation is increased to meet the high demand of heme production in such tissues as bone marrow and liver.

The amino acid glycine can be synthesized within the cell through several metabolic pathways $[37,38]$. For example, the serine hydroxymethyltransferase SHMT2 catalyzes the formation of glycine from serine and tetrahydrofolate within the mitochondria [39,40]. Glycine can also be produced from other sources such as choline and threonine [37,38]. Currently, the contribution of endogenously synthesized glycine to heme biosynthesis is unclear.

In addition to its biosynthesis, glycine can be imported into cells by transporters. Neuronal tissues use glycine transporters GLYT1 and GLYT2 to take up glycine [41-43]. 
A recent transcriptome analysis detected GLYT1 as one of the mRNAs enriched in developing erythrocytes [44]. The Glyt1 knockout mice developed microcytic hypochromic anemia [45]. Glycine uptake and heme production were both reduced in the Glyt1-deficient erythroid cells [45]. These studies suggest that GLYT1 may be the primary transporter supplying glycine for heme synthesis in erythroid tissues. After entering the cytoplasm, glycine needs to be delivered to the mitochondria for heme synthesis. The solute carrier family protein SLC25A38 was proposed to transport glycine across the inner membrane of mitochondria [46]. Mutation of this gene caused nonsyndromic congenital sideroblastic anemia in humans [46,47]. Deletion of $S L C 25 A 38$ homolog in yeast led to reduced ALA production, indicating that this carrier protein regulates the first step of porphyrin synthesis [46].

\subsection{Regulation of heme synthesis enzymes}

While the regulatory mechanisms for most enzymes in heme biogenesis are unclear, the first and final enzymes have been shown to be regulated by iron status, oxygen levels, and other related factors.

Aminolevulinic acid synthase (ALAS) is the enzyme catalyzing the first step of heme biosynthesis. Two ALAS paralogs exist in vertebrate animals. The expression of $A L A S 1$, a ubiquitously expressed gene, is stimulated by the circadian clock gene NPAS 2 and repressed by heme [7,48,49]. $A L A S 2$, or $e A L A S$, is specifically expressed in erythroid cells [50]. The expression of ALAS2 is regulated posttranscriptionally by iron through the iron regulatory protein 1 (IRP1) [51,52]. When cellular iron is insufficient, IRP1 binds to the iron regulatory element in the $5^{\prime}$ untranslated region of ALAS2 mRNA, leading to its reduced translation [51,52]. Besides, ALAS2 expression is induced by hypoxia [53]. Hypoxia-inducible factor $1 \alpha(\mathrm{HIF} 1 \alpha)$ can activate the transcription of ALAS2 [54].

Ferrochelatase $(\mathrm{FECH})$ catalyzes the final step of heme synthesis - the incorporation of iron into protoporphyrin IX (PPIX). Similar to ALAS2, the expression of FECH is also regulated by oxygen levels through HIF1 $\alpha$ [55]. Animal FECHs contain iron-sulfur [2Fe-2S] clusters. Both the stability and the enzymatic activity of metazoan $\mathrm{FECH}$ proteins are regulated by iron availability as well as the production of iron-sulfur clusters [56,57]. Because of the presence of $[2 \mathrm{Fe}-2 \mathrm{~S}]$ clusters, animal FECHs are also regulated by mitochondrial $\mathrm{pH}$ and redox potential. For example, alkalization of mitochondria due to deficiency of ATPase inhibitory factor 1 reduced the activity of $\mathrm{FECH}$ and the production of heme [57].

The insertion of iron into PPIX is facilitated by the ATP binding cassette protein ABCB10. ABCB10 physically interacts with both mitoferrin 1 and FECH [58]. This interaction ensures that the imported iron is preferentially utilized for heme production. Deletion of $A b c b 10$ in mice impaired heme biosynthesis, erythropoiesis, and caused embryonic lethality [59]. Tissue-specific knockout of $A b c b 10$ in mouse hematopoietic cells resulted in accumulation of iron and PPIX in reticulocytes, confirming its role in the final step of heme synthesis pathway [59].

\subsection{Transport of heme synthesis intermediates}

The biosynthesis of heme starts and ends in the mitochondria, while four intermediate reactions take place in the cytosol. Therefore, the products of several reactions need to be shuttled between the mitochondria and the cytosol in order to be used as substrates for the subsequent reactions (Figure 1). First, ALA needs to be transported across the mitochondrial membranes to the cytosol, where the subsequent four heme synthesis enzymes are located. A study suggested that ABCB10 might mediate this translocating event [60]. However, other biochemical and genetic studies indicate that $\mathrm{ABCB} 10$ is more likely to be involved in the final step of heme synthesis, as discussed above [59,61].

Coproporphyrinogen III (CPgenIII) is formed from ALA via four enzyme-catalyzed reactions in the cytosol. The enzyme receiving CPgenIII, coproporphyrinogen oxidase $(\mathrm{CPOX})$, is anchored on the mitochondrial matrix with the active site in the intermembrane space [62]. ABCB6 was proposed to be responsible for transporting CPgenIII across the mitochondrial outer membrane [63]. However, a more recent study revealed that ABCB6 specifies the blood group Langereis and is not required for erythropoiesis [64]. Therefore, the real identity of CpgenIII transporter remains elusive.

The product of CPOX, protoporphyrinogen IX (PPgenIX), is then converted into PPIX by protoporphyrinogen oxidase (PPOX), which forms a complex with the final enzyme FECH in the mitochondrial matrix $[62,65,66]$. A recent report showed that PPgenIX may be transported to PPOX by transmembrane protein 14C (TMEM14C) [67]. TMEM14C was first identified by a large-scale bioinformatics analysis to co-express with heme synthesis genes [68]. Silencing of tmem $14 c$ with morpholinos resulted in profound anemia in zebrafish embryos [68]. Tmem 14cdeficient mice die during embryonic development [67]. These mutant mice had CPgenIII accumulation accompanied by reduced level of PPIX in the fetal liver. This observation was further validated by the rescue of heme defects with a PPIX analog, deuteroporphyrin IX, in Tmem14cdeficient cells [67]. As a transmembrane protein localized to the inner mitochondrial membrane, TMEM14C may mediate the import of PPgenIX into the mitochondrial matrix [67].

\section{Heme transport and regulation of heme ho- meostasis}

Besides biosynthesis and degradation, cellular heme homeostasis is also maintained by trafficking. A number of mol- 
ecules and pathways have been identified to transport heme within and between cells (Table 1).

\subsection{Heme import}

Heme is absorbed by human intestine at a much higher efficiency than inorganic iron, indicating the presence of specific heme uptake system. Heme carrier protein 1 (HCP1) was reported to be a heme importer in mammalian intestine [69]. However, HCP1 is actually a high-affinity, proton coupled folate transporter [82]. It remains to be tested whether the low affinity heme transport activity of this folate transporter has physiological relevance.

By using the model organism Caenorhabditis elegans, Rajagopal et al. [70] identified a high-affinity heme importer-heme responsive gene-1 (HRG-1). Because C. elegans and related nematodes are unable to synthesize heme, they completely rely on food for heme nutrition. In the worm intestine, HRG-1 is responsible for mobilizing heme out of the endosomal-lysosomal organelles, whereas its paralog HRG-4 imports dietary heme through the apical surface of intestinal cells. The heme transport activities of $C$. elegans HRG-1 and HRG-4 have been verified in worms, Xenopus oocytes, and yeast $[70,83]$. In a similar way, the homolog of HRG-4 in Leishmania amazonensis, Leishmania Heme Response-1 (LHR-1), mediates heme uptake in the parasites [84]. HRG-1, HRG-4, and LHR-1 are all transcriptionally up-regulated under heme-limiting conditions [70,84].

Another C. elegans gene, hrg-2, is also induced by heme deficiency [85]. HRG-2 localizes to the endoplasmic reticulum and apical plasma membrane of the hypodermal cells. It binds heme and facilitates heme utilization by the hypodermis of worms. The precise function of HRG-2 in heme homeostasis is currently unclear.

\subsection{Heme export}

The Feline Leukemia Virus subgroup C receptor (FLVCR or FLVCR1) is the first heme transporter identified in eukaryotes [71]. Two isoforms of FLVCR1, FLVCR1a and FLVCR1b, may play distinct roles in mammalian heme homeostasis. FLVCR1a is a heme exporter [71], whereas FLVCR1b may be an intracellular heme transporter [74]. In macrophages of the reticuloendothelial system, FLVCR1a exports heme that is derived from ingested senescent red blood cells [72]. The heme export activity of FLVCR1a was also reported in hepatocytes and T cells [86,87]. Hypoxia induces the expression of FLVCR through HIF $2 \alpha$ and the HIF-dependent transcription factor v-ets avian erythroblastosis virus E26 oncogene homolog 1 (ETS1) [88].

Korolnek et al. [73] identified the multidrug resistance protein MRP-5/ABCC5 as another heme exporter in animals. In C. elegans, MRP-5 localizes to the basolateral surface of the intestinal cells and mediates heme export out of the intestine. Deletion of $m r p-5$ results in embryonic death, which is due to impaired heme transfer to extra-intestinal tissues [73]. In vertebrate cells, MRP-5 localizes to both plasma membrane and intracellular compartments [73]. Deficiency of $m r p-5$ led to reduced heme loading into the secretory compartments in mouse embryonic fibroblasts and profound anemia in zebrafish embryos [73].

\subsection{Intracellular heme transport}

Within the cell, heme is produced in the mitochondria. However, many hemoproteins are present in other subcellular compartments. It was proposed that FLVCR1b, the mitochondrial isoform of FLVCR1a, is responsible for translocating heme out of the mitochondria [74]. Based on the observations that the Flvcrl (the gene expresses both Flvcrla and Flvcrlb) knockout mice die during embryonic development and Flvcrla knockout mice had normal erythropoiesis [72,74], Chiabrando et al. [74] concluded that the phenotypes observed in Flverl knockout mice were due to deficiency of Flvcrlb. Furthermore, silencing of FLVCRIb resulted in heme accumulation within the mitochondria. Therefore, it was proposed that FLVCR1b regulates heme export from the mitochondria while FLVCR1a regulates heme efflux through the plasma membrane [74].

Once inside the cytoplasm, heme needs to be delivered to target hemoproteins. Glyceraldehyde-3-phosphate dehy-

Table 1 Proteins involved in heme transport in animals

\begin{tabular}{|c|c|c|c|}
\hline Category & Protein & Reported function & Reference \\
\hline \multirow[t]{2}{*}{ heme import } & HCP1 & import heme into intestinal cells & {$[69]$} \\
\hline & HRG-4 & import heme into intestinal cells & [70] \\
\hline \multirow[t]{2}{*}{ heme export } & FLVCR & export heme out of macrophages & {$[71,72]$} \\
\hline & MRP5 & export heme out of intestinal cells & {$[73]$} \\
\hline \multirow[t]{3}{*}{ intracellular heme transport } & FLVCR1b & export heme out of mitochondria & [74] \\
\hline & HRG1 & export heme out of endosomal-lysosomal organelles and phagolysosomes & {$[70,75]$} \\
\hline & HSP90 & insert heme into sGC & [77] \\
\hline \multirow[t]{2}{*}{ intercellular heme transport } & hemopexin & bind heme in the blood and deliver heme to hepatocytes and macrophages & [78-80] \\
\hline & HRG-3 & deliver heme from maternal intestine to developing oocytes & {$[81]$} \\
\hline
\end{tabular}


drogenase (GAPDH) and $90 \mathrm{kD}$ heat-shock protein (HSP90) were reported to mediate heme insertion into iNOS and sGC, respectively. GAPDH is known to be an enzyme catalyzing the conversion of glyceraldehyde-3-phosphate into 1,3-bisphosphoglycerate. Chakravarti et al. [76] found that GAPDH interacts with both heme and iNOS. Knockdown of $G A P D H$ or mutation of the heme-binding site in GAPDH significantly reduced heme incorporation into iNOS. The product of iNOS, nitric oxide (NO), also inhibited heme insertion into iNOS through $S$-nitrosylation of GAPDH [76]. Heme insertion into sGC was found to be mediated by HSP90, which preferentially interacts with apo-sGC [77]. HSP90-mediated heme incorporation converts apo-sGC into a mature active form that is responsive to NO [77]. The insertion of heme into sGC is positively regulated by NO [89].

HRG-1 and its mammalian homologs also transport heme within the cell. As discussed above, C. elegans HRG-1 transports heme from the endosomal-lysosomal organelles to the cytosol within the intestinal cells [70]. Similarly, mammalian HRG1 transports heme from the phagolysosomes to the cytosol of the reticuloendothelial macrophages [75]. During erythrophagocytosis, macrophage phagolysosomes are responsible for breaking down ingested red blood cells to release heme. HRG1 specifically localizes to the phagolysosomal membranes during erythrophagocytosis. Silencing of HRG1 significantly reduced the heme levels in the cytosol of bone marrow-derive macrophages [75]. Knockdown of $\mathrm{hrgl}$ in zebrafish resulted in hypochromic anemia [70]. The expression of HRG1 in reticuloendothelial macrophages is up-regulated by both erythrophagocytosis and heme [75]. Thus, vertebrate HRG1 plays a critical role in recycling heme and heme iron from the senescent red blood cells [75].

\subsection{Intercellular heme transport}

Hemopexin is a high-affinity heme binding protein in the blood [78]. It accepts heme from FLVCR through direct protein-protein interactions [90]. Binding of heme by hemopexin may be a critical step in the recycling of heme during erythrophagocytosis. Low-density lipoprotein receptor-related protein (LRP1) was found to be the receptor for hemopexin [79]. LRP1 is expressed in several cell types including hepatocytes, macrophages, neurons, and syncytiotrophoblasts. Hada et al. [80] confirmed that hepatocytes and macrophages are able to take up the hemopexin-heme complex. Uptake of hemopexin-bound heme but not free heme was inhibited by treating the cells with the inhibitor of clathrin-mediated endocytosis, validating that the hemopexin-heme complex enters cells through endocytosis [80].

The heme responsive gene 3 (HRG-3) is an intercellular heme trafficking protein in C. elegans [81]. Heme deficiency induces $\mathrm{hrg}-3$ expression in the worm intestine. HRG-3 protein binds stoichiometric amounts of heme and is secreted into the worm circulation pseudocoelom. HRG-3heme can be taken up by tissues such as developing oocytes.
During this process, heme is transferred from maternal intestine to the oocytes and embryos. The progeny of hrg-3deficient worms are arrested during embryonic development or at early larval stages due to heme deficiency. Therefore, HRG-3 plays a critical physiological role in delivering heme to oocytes and related tissues in worms.

\section{Conclusion}

Sixty years ago, Shemin and other researchers [91,92] discovered the enzymes and substrates for the heme synthesis pathway. Since then, heme-related research has attracted a lot of interest. The recent years have witnessed a rapid expansion of knowledge in heme metabolism. A number of regulatory molecules and mechanisms have been identified in iron uptake and heme synthesis pathways. Importantly, discoveries of heme transporters such as FLVCR and HRG1 proved that heme does not move around freely in the cell. Several key gaps still remain in our knowledge of heme metabolism: (i) What is the real identity of the heme receptor in human intestine? (ii) What mechanisms regulate the intermediate steps of heme synthesis? (iii) How does heme enter nuclei, lysosomes, peroxisomes, and the secretory pathway? By using yeast, worm, zebrafish, and mouse as the model systems, researchers are actively trying to address these questions and to further our understanding of heme metabolism.

This work was supported by the National Natural Science Foundation of China (31371435), the National Key Basic Research Program of China (2015CB150300), the Fundamental Research Funds for the Central Universities, and the Thousand Youth Talents Program of China.

1 Korolnek T, Hamza I. Like iron in the blood of the people: the requirement for heme trafficking in iron metabolism. Front Pharmacol, 2014, 5: 1-13

2 Severance S, Hamza I. Trafficking of heme and porphyrins in metazoa. Chem Rev, 2009, 109: 4596-4616

3 Haldar M, Kohyama M, So AY, Wumesh KC, Wu XD, Briseno CG, Satpathy AT, Kretzer NM, Arase H, Rajasekaran NS, Wang L, Egawa T, Igarashi K, Baltimore D, Murphy TL, Murphy KM. Heme-mediated SPI-C induction promotes monocyte differentiation into iron-recycling macrophages. Cell, 2014, 156: 1223-1234

4 Ogawa K, Sun J, Taketani S, Nakajima O, Nishitani C, Sassa S, Hayashi N, Yamamoto M, Shibahara S, Fujita H, Igarashi K. Heme mediates derepression of Maf recognition element through direct binding to transcription repressor Bach1. EMBO J, 2001, 20: 2835-2843

5 Suzuki H, Tashiro S, Hira S, Sun J, Yamazaki C, Zenke Y, Ikeda-Saito M, Yoshida M, Igarashi K. Heme regulates gene expression by triggering Crm1-dependent nuclear export of Bach1. EMBO J, 2004, 23: 2544-2553

6 Warnatz HJ, Schmidt D, Manke T, Piccini I, Sultan M, Borodina T, Balzereit D, Wruck W, Soldatov A, Vingron M, Lehrach H, Yaspo ML. The BTB and CNC homology 1 (BACH1) target genes are involved in the oxidative stress response and in control of the cell cycle. J Biol Chem, 2011, 286: 23521-23532

7 Kaasik K, Lee CC. Reciprocal regulation of haem biosynthesis and the circadian clock in mammals. Nature, 2004, 430: 467-471 
8 Lukat-Rodgers GS, Correia C, Botuyan MV, Mer G, Rodgers KR. Heme-based sensing by the mammalian circadian protein clock. Inorg Chem, 2010, 49: 6349-6365

9 Raghuram S, Stayrook KR, Huang P, Rogers PM, Nosie AK, McClure DB, Burris LL, Khorasanizadeh S, Burris TP, Rastinejad F. Identification of heme as the ligand for the orphan nuclear receptors REV-ERB $\alpha$ and REV-ERB $\beta$. Nat Struct Mol Biol, 2007, 14: 1207-1213

10 Yin L, Wu N, Curtin JC, Qatanani M, Szwergold NR, Reid RA, Waitt GM, Parks DJ, Pearce KH, Wisely GB, Lazar MA. REV-ERB $\alpha$, a heme sensor that coordinates metabolic and circadian pathways. Science, 2007, 318: 1786-1789

11 Shen J, Sheng XP, Chang ZN, Wu Q, Wang S, Xuan ZL, Li D, Wu YL, Shang YJ, Kong XT, Yu L, Li L, Ruan KC, Hu HY, Huang Y, Hui LJ, Xie D, Wang FD, Hu RG. Iron metabolism regulates p53 signaling through direct heme-p53 interaction and modulation of p53 localization, stability, and function. Cell Rep, 2014, 7: 180-193

12 Faller M, Matsunaga M, Yin S, Loo JA, Guo F. Heme is involved in microrna processing. Nat Struct Mol Biol, 2007, 14: 23-29

13 Quick-Cleveland J, Jacob JP, Weitz SH, Shoffner G, Senturia R, Guo F. The DGCR8 RNA-binding heme domain recognizes primary micrornas by clamping the hairpin. Cell Rep, 2014, 7: 1994-2005

14 Weitz SH, Gong M, Barr I, Weiss S, Guo F. Processing of microRNA primary transcripts requires heme in mammalian cells. Proc Natl Acad Sci USA, 2014, 111: 1861-1866

15 Naito Y, Takagi T, Higashimura Y. Heme oxygenase-1 and anti-inflammatory M2 macrophages. Arch Biochem Biophys, 2014, 564: 83-88

16 Wegiel B, Nemeth Z, Correa-Costa M, Bulmer AC, Otterbein LE. Heme oxygenase-1: a metabolic nike. Antioxid Redox Signal, 2014, 20: $1709-1722$

17 Andrews NC. Disorders of iron metabolism. N Engl J Med, 1999, 341: 1986-1995

18 Chen C, Paw BH. Cellular and mitochondrial iron homeostasis in vertebrates. Biochim Biophys Acta, 2012, 1823: 1459-1467

19 Ishikawa Y, Maeda M, Pasham M, Aguet F, Tacheva-Grigorova SK, Masuda T, Yi H, Lee SU, Xu J, Teruya-Feldstein J, Ericsson M, Mullally A, Heuser J, Kirchhausen T, Maeda T. Role of the clathrin adaptor PICALM in normal hematopoiesis and polycythemia vera pathophysiology. Haematologica, 2015, 100: 439-451

20 Scotland PB, Heath JL, Conway AE, Porter NB, Armstrong MB, Walker JA, Klebig ML, Lavau CP, Wechsler DS. The picalm protein plays a key role in iron homeostasis and cell proliferation. PLoS One, 2012, 7: e44252

21 Suzuki M, Tanaka H, Tanimura A, Tanabe K, Oe N, Rai S, Kon S, Fukumoto M, Takei K, Abe T, Matsumura I, Kanakura Y, Watanabe $\mathrm{T}$. The clathrin assembly protein picalm is required for erythroid maturation and transferrin internalization in mice. PLoS One, 2012, 7 : e31854

22 Chen C, Garcia-Santos D, Ishikawa Y, Seguin A, Li L, Fegan KH, Hildick-Smith GJ, Shah DI, Cooney JD, Chen W, King MJ, Yien YY, Schultz IJ, Anderson H, Dalton AJ, Freedman ML, Kingsley PD, Palis J, Hattangadi SM, Lodish HF, Ward DM, Kaplan J, Maeda T, Ponka P, Paw BH. Snx3 regulates recycling of the transferrin receptor and iron assimilation. Cell Metab, 2013, 17: 343-352

23 Lim JE, Jin O, Bennett C, Morgan K, Wang F, Trenor CC 3rd, Fleming MD, Andrews NC. A mutation in Sec1511 causes anemia in hemoglobin deficit (hbd) mice. Nat Genet, 2005, 37: 1270-1273

24 Zhang AS, Sheftel AD, Ponka P. The anemia of "haemoglobin-deficit" ( $\mathrm{hbd} / \mathrm{hbd}$ ) mice is caused by a defect in transferrin cycling. Exp Hematol, 2006, 34: 593-598

25 Ohgami RS, Campagna DR, Greer EL, Antiochos B, McDonald A, Chen J, Sharp JJ, Fujiwara Y, Barker JE, Fleming MD. Identification of a ferrireductase required for efficient transferrin-dependent iron uptake in erythroid cells. Nat Genet, 2005, 37: 1264-1269

26 Ohgami RS, Campagna DR, McDonald A, Fleming MD. The steap proteins are metalloreductases. Blood, 2006, 108: 1388-1394

27 Fleming MD, Romano MA, Su MA, Garrick LM, Garrick MD, An- drews NC. Nramp2 is mutated in the anemic Belgrade (b) rat: evidence of a role for Nramp2 in endosomal iron transport. Proc Natl Acad Sci USA, 1998, 95: 1148-1153

28 Dong XP, Cheng X, Mills E, Delling M, Wang F, Kurz T, Xu H. The type IV mucolipidosis-associated protein TRPML1 is an endolysosomal iron release channel. Nature, 2008, 455: 992-996

29 Cheng X, Zhang X, Gao Q, Ali Samie M, Azar M, Tsang WL, Dong L, Sahoo N, Li X, Zhuo Y, Garrity AG, Wang X, Ferrer M, Dowling $\mathrm{J}, \mathrm{Xu} \mathrm{L}$, Han $\mathrm{R}, \mathrm{Xu} \mathrm{H}$. The intracellular $\mathrm{Ca}^{2+}$ channel MCOLN1 is required for sarcolemma repair to prevent muscular dystrophy. Nat Med, 2014, 20: 1187-1192

30 Frey AG, Nandal A, Park JH, Smith PM, Yabe T, Ryu MS, Ghosh MC, Lee J, Rouault TA, Park MH, Philpott CC. Iron chaperones PCBP1 and PCBP2 mediate the metallation of the dinuclear iron enzyme deoxyhypusine hydroxylase. Proc Natl Acad Sci USA, 2014, 111: 8031-8036

31 Nandal A, Ruiz JC, Subramanian P, Ghimire-Rijal S, Sinnamon RA, Stemmler TL, Bruick RK, Philpott CC. Activation of the hif prolyl hydroxylase by the iron chaperones PCBP1 and PCBP2. Cell Metab, 2011, 14: 647-657

32 Shi H, Bencze KZ, Stemmler TL, Philpott CC. A cytosolic iron chaperone that delivers iron to ferritin. Science, 2008, 320: 1207-1210

33 Shaw GC, Cope JJ, Li L, Corson K, Hersey C, Ackermann GE, Gwynn B, Lambert AJ, Wingert RA, Traver D, Trede NS, Barut BA, Zhou Y, Minet E, Donovan A, Brownlie A, Balzan R, Weiss MJ, Peters LL, Kaplan J, Zon LI, Paw BH. Mitoferrin is essential for erythroid iron assimilation. Nature, 2006, 440: 96-100

34 Paradkar PN, Zumbrennen KB, Paw BH, Ward DM, Kaplan J. Regulation of mitochondrial iron import through differential turnover of mitoferrin 1 and mitoferrin 2. Mol Cell Biol, 2009, 29: 1007-1016

35 Labbe RF, Kurumada T, Onisawa J. The role of succinyl-coa synthetase in the control of heme biosynthesis. Biochim Biophys Acta, 1965, 111: 403-415

36 Onisawa J, Labbe RF. Terminal oxidation in the regulation of heme biosynthesis. Science, 1963, 140: 1326-1327

37 Locasale JW. Serine, glycine and one-carbon units: cancer metabolism in full circle. Nat Rev Cancer, 2013, 13: 572-583

38 Wang W, Wu Z, Dai Z, Yang Y, Wang J, Wu G. Glycine metabolism in animals and humans: implications for nutrition and health. Amino Acids, 2013, 45: 463-477

39 Anderson DD, Quintero CM, Stover PJ. Identification of a de novo thymidylate biosynthesis pathway in mammalian mitochondria. Proc Natl Acad Sci USA, 2011, 108: 15163-15168

40 di Salvo ML, Contestabile R, Paiardini A, Maras B. Glycine consumption and mitochondrial serine hydroxymethyltransferase in cancer cells: the heme connection. Med Hypotheses, 2013, 80: 633-636

41 Guastella J, Brecha N, Weigmann C, Lester HA, Davidson N. Cloning, expression, and localization of a rat brain high-affinity glycine transporter. Proc Natl Acad Sci USA, 1992, 89: 7189-7193

42 Harvey RJ, Yee BK. Glycine transporters as novel therapeutic targets in schizophrenia, alcohol dependence and pain. Nat Rev Drug Discov, 2013, 12: 866-885

43 Liu QR, Lopez-Corcuera B, Mandiyan S, Nelson H, Nelson N. Cloning and expression of a spinal cord- and brain-specific glycine transporter with novel structural features. J Biol Chem, 1993, 268: 22802-22808

44 An X, Schulz VP, Li J, Wu K, Liu J, Xue F, Hu J, Mohandas N, Gallagher PG. Global transcriptome analyses of human and murine terminal erythroid differentiation. Blood, 2014, 123: 3466-3477

45 Schranzhofer M, Bergeron R, dos Santos DG, Ponka P. Glycine transporter 1 plays a crucial role in hemoglobinization. Am J Hematol, 2013, 88: E32-E33

46 Guernsey DL, Jiang H, Campagna DR, Evans SC, Ferguson M, Kellogg MD, Lachance M, Matsuoka M, Nightingale M, Rideout A, Saint-Amant L, Schmidt PJ, Orr A, Bottomley SS, Fleming MD, Ludman M, Dyack S, Fernandez CV, Samuels ME. Mutations in mitochondrial carrier family gene SLC25A38 cause nonsyndromic autosomal recessive congenital sideroblastic anemia. Nat Genet, 2009, 
41: 651-653

47 Liu G, Guo S, Kang H, Zhang F, Hu Y, Wang L, Li M, Ru Y, Camaschella C, Han B, Nie G. Mutation spectrum in chinese patients affected by congenital sideroblastic anemia and a search for a genotype-phenotype relationship. Haematologica, 2013, 98: e158-e160

48 Gotoh S, Nakamura T, Kataoka T, Taketani S. Egr-1 regulates the transcriptional repression of mouse $\delta$-aminolevulinic acid synthase 1 by heme. Gene, 2011, 472: 28-36

49 Yoshino K, Munakata H, Kuge O, Ito A, Ogishima T. Haeme-regulated degradation of $\delta$-aminolevulinate synthase 1 in rat liver mitochondria. J Biochem, 2007, 142: 453-458

50 Riddle RD, Yamamoto M, Engel JD. Expression of $\delta$-aminolevulinate synthase in avian cells: separate genes encode erythroid-specific and nonspecific isozymes. Proc Natl Acad Sci USA, 1989, 86: 792-796

51 Dandekar T, Stripecke R, Gray NK, Goossen B, Constable A, Johansson HE, Hentze MW. Identification of a novel iron-responsive element in murine and human erythroid $\delta$-aminolevulinic acid synthase mRNA. EMBO J, 1991, 10: 1903-1909

52 Hentze MW, Muckenthaler MU, Andrews NC. Balancing acts: molecular control of mammalian iron metabolism. Cell, 2004, 117: 285-297

53 Hofer T, Wenger RH, Kramer MF, Ferreira GC, Gassmann M. Hypoxic up-regulation of erythroid 5-aminolevulinate synthase. Blood, 2003, 101: 348-350

54 Zhang FL, Shen GM, Liu XL, Wang F, Zhao HL, Yu J, Zhang JW. Hypoxic induction of human erythroid-specific $\delta$-aminolevulinate synthase mediated by hypoxia-inducible factor 1 . Biochemistry, 2011, 50: 1194-1202

55 Liu YL, Ang SO, Weigent DA, Prchal JT, Bloomer JR. Regulation of ferrochelatase gene expression by hypoxia. Life Sci, 2004, 75: 2035-2043

56 Crooks DR, Ghosh MC, Haller RG, Tong WH, Rouault TA. Posttranslational stability of the heme biosynthetic enzyme ferrochelatase is dependent on iron availability and intact iron-sulfur cluster assembly machinery. Blood, 2010, 115: 860-869

57 Shah DI, Takahashi-Makise N, Cooney JD, Li L, Schultz IJ, Pierce EL, Narla A, Seguin A, Hattangadi SM, Medlock AE, Langer NB, Dailey TA, Hurst SN, Faccenda D, Wiwczar JM, Heggers SK, Vogin G, Chen W, Chen C, Campagna DR, Brugnara C, Zhou Y, Ebert BL, Danial NN, Fleming MD, Ward DM, Campanella M, Dailey HA, Kaplan J, Paw BH. Mitochondrial Atpif1 regulates haem synthesis in developing erythroblasts. Nature, 2012, 491: 608-612

58 Chen W, Dailey HA, Paw BH. Ferrochelatase forms an oligomeric complex with mitoferrin-1 and Abcb10 for erythroid heme biosynthesis. Blood, 2010, 116: 628-630

59 Yamamoto M, Arimura H, Fukushige T, Minami K, Nishizawa Y, Tanimoto A, Kanekura T, Nakagawa M, Akiyama S, Furukawa T. Abcb10 role in heme biosynthesis in vivo: Abcb10 knockout in mice causes anemia with protoporphyrin IX and iron accumulation. Mol Cell Biol, 2014, 34: 1077-1084

60 Bayeva M, Khechaduri A, Wu R, Burke MA, Wasserstrom JA, Singh N, Liesa M, Shirihai OS, Langer NB, Paw BH, Ardehali H. ATP-binding cassette B10 regulates early steps of heme synthesis. Circ Res, 2013, 113: 279-287

61 Chen W, Paradkar PN, Li L, Pierce EL, Langer NB, Takahashi-Makise N, Hyde BB, Shirihai OS, Ward DM, Kaplan J, Paw BH. Abcb10 physically interacts with mitoferrin-1 (Slc25a37) to enhance its stability and function in the erythroid mitochondria. Proc Natl Acad Sci USA, 2009, 106: 16263-16268

62 Rhee HW, Zou P, Udeshi ND, Martell JD, Mootha VK, Carr SA, Ting AY. Proteomic mapping of mitochondria in living cells via spatially restricted enzymatic tagging. Science, 2013, 339: 1328-1331

63 Krishnamurthy PC, Du G, Fukuda Y, Sun D, Sampath J, Mercer KE, Wang J, Sosa-Pineda B, Murti KG, Schuetz JD. Identification of a mammalian mitochondrial porphyrin transporter. Nature, 2006, 443: 586-589

64 Helias V, Saison C, Ballif BA, Peyrard T, Takahashi J, Takahashi H,
Tanaka M, Deybach JC, Puy H, Le Gall M, Sureau C, Pham BN, Le Pennec PY, Tani Y, Cartron JP, Arnaud L. Abcb6 is dispensable for erythropoiesis and specifies the new blood group system langereis. Nat Genet, 2012, 44: 170-173

65 Ferreira GC, Andrew TL, Karr SW, Dailey HA. Organization of the terminal two enzymes of the heme biosynthetic pathway. Orientation of protoporphyrinogen oxidase and evidence for a membrane complex. J Biol Chem, 1988, 263: 3835-3839

66 Koch M, Breithaupt C, Kiefersauer R, Freigang J, Huber R, Messerschmidt A. Crystal structure of protoporphyrinogen ix oxidase: a key enzyme in haem and chlorophyll biosynthesis. EMBO J, 2004, 23: 1720-1728

67 Yien YY, Robledo RF, Schultz IJ, Takahashi-Makise N, Gwynn B, Bauer DE, Dass A, Yi G, Li L, Hildick-Smith GJ, Cooney JD, Pierce EL, Mohler K, Dailey TA, Miyata N, Kingsley PD, Garone C, Hattangadi SM, Huang H, Chen W, Keenan EM, Shah DI, Schlaeger TM, DiMauro S, Orkin SH, Cantor AB, Palis J, Koehler CM, Lodish HF, Kaplan J, Ward DM, Dailey HA, Phillips JD, Peters LL, Paw BH. TMEM14C is required for erythroid mitochondrial heme metabolism. J Clin Invest, 2014, 124: 4294-4304

68 Nilsson R, Schultz IJ, Pierce EL, Soltis KA, Naranuntarat A, Ward DM, Baughman JM, Paradkar PN, Kingsley PD, Culotta VC, Kaplan J, Palis J, Paw BH, Mootha VK. Discovery of genes essential for heme biosynthesis through large-scale gene expression analysis. Cell Metab, 2009, 10: 119-130

69 Shayeghi M, Latunde-Dada GO, Oakhill JS, Laftah AH, Takeuchi K, Halliday N, Khan Y, Warley A, McCann FE, Hider RC, Frazer DM, Anderson GJ, Vulpe CD, Simpson RJ, McKie AT. Identification of an intestinal heme transporter. Cell, 2005, 122: 789-801

70 Rajagopal A, Rao AU, Amigo J, Tian M, Upadhyay SK, Hall C, Uhm S, Mathew MK, Fleming MD, Paw BH, Krause M, Hamza I. Haem homeostasis is regulated by the conserved and concerted functions of HRG-1 proteins. Nature, 2008, 453: 1127-1131

71 Quigley JG, Yang ZT, Worthington MT, Phillips JD, Sabo KM, Sabath DE, Berg CL, Sassa S, Wood BL, Abkowitz JL. Identification of a human heme exporter that is essential for erythropoiesis. Cell, 2004, 118: 757-766

72 Keel SB, Doty RT, Yang Z, Quigley JG, Chen J, Knoblaugh S, Kingsley PD, de Domenico I, Vaughn MB, Kaplan J, Palis J, Abkowitz JL. A heme export protein is required for red blood cell differentiation and iron homeostasis. Science, 2008, 319: 825-828

73 Korolnek T, Zhang J, Beardsley S, Scheffer GL, Hamza I. Control of metazoan heme homeostasis by a conserved multidrug resistance protein. Cell Metab, 2014, 19: 1008-1019

74 Chiabrando D, Marro S, Mercurio S, Giorgi C, Petrillo S, Vinchi F, Fiorito V, Fagoonee S, Camporeale A, Turco E, Merlo GR, Silengo L, Altruda F, Pinton P, Tolosano E. The mitochondrial heme exporter FLVCR1b mediates erythroid differentiation. J Clin Invest, 2012, 122: 4569-4579

75 White C, Yuan X, Schmidt PJ, Bresciani E, Samuel TK, Campagna D, Hall C, Bishop K, Calicchio ML, Lapierre A, Ward DM, Liu P, Fleming MD, Hamza I. HRG1 is essential for heme transport from the phagolysosome of macrophages during erythrophagocytosis. Cell Metab, 2013, 17: 261-270

76 Chakravarti R, Aulak KS, Fox PL, Stuehr DJ. Gapdh regulates cellular heme insertion into inducible nitric oxide synthase. Proc Natl Acad Sci USA, 2010, 107: 18004-18009

77 Ghosh A, Stuehr DJ. Soluble guanylyl cyclase requires heat shock protein 90 for heme insertion during maturation of the no-active enzyme. Proc Natl Acad Sci USA, 2012, 109: 12998-13003

78 Hrkal Z, Vodrazka Z, Kalousek I. Transfer of heme from ferrihemoglobin and ferrihemoglobin isolated chains to hemopexin. Eur J Biochem, 1974, 43: 73-78

79 Hvidberg V, Maniecki MB, Jacobsen C, Hojrup P, Moller HJ, Moestrup SK. Identification of the receptor scavenging hemopexin-heme complexes. Blood, 2005, 106: 2572-2579

80 Hada H, Shiraki T, Watanabe-Matsui M, Igarashi K. Hemopexin-dependent heme uptake via endocytosis regulates the Bach1 transcription repressor and heme oxygenase gene activation. Biochim 
Biophys Acta, 2014, 1840: 2351-2360

81 Chen C, Samuel TK, Sinclair J, Dailey HA, Hamza I. An intercellular heme-trafficking protein delivers maternal heme to the embryo during development in C. Elegans. Cell, 2011, 145: 720-731

82 Qiu A, Jansen M, Sakaris A, Min SH, Chattopadhyay S, Tsai E, Sandoval C, Zhao R, Akabas MH, Goldman ID. Identification of an intestinal folate transporter and the molecular basis for hereditary folate malabsorption. Cell, 2006, 127: 917-928

83 Yuan X, Protchenko O, Philpott CC, Hamza I. Topologically conserved residues direct heme transport in HRG-1-related proteins. J Biol Chem, 2012, 287: 4914-4924

84 Huynh C, Yuan X, Miguel DC, Renberg RL, Protchenko O, Philpott CC, Hamza I, Andrews NW. Heme uptake by Leishmania amazonensis is mediated by the transmembrane protein LHR1. PLoS Pathog, 2012, 8: e1002795

85 Chen C, Samuel TK, Krause M, Dailey HA, Hamza I. Heme utilization in the caenorhabditis elegans hypodermal cells is facilitated by heme-responsive gene-2. J Biol Chem, 2012, 287: 9601-9612

86 Philip M, Funkhouser SA, Chiu EY, Phelps SR, Delrow JJ, Cox J, Fink PJ, Abkowitz JL. Heme exporter FLVCR is required for T cell development and peripheral survival. J Immunol, 2015, 194:
1677-1685

87 Vinchi F, Ingoglia G, Chiabrando D, Mercurio S, Turco E, Silengo L, Altruda F, Tolosano E. Heme exporter FLVCR1a regulates heme synthesis and degradation and controls activity of cytochromes P450. Gastroenterology, 2014, 146: 1325-1338

88 Fiorito V, Neri F, Pala V, Silengo L, Oliviero S, Altruda F, Tolosano E. Hypoxia controls Flvcr1 gene expression in Caco2 cells through HIF2 $\alpha$ and ETS1. Biochim Biophys Acta, 2014, 1839: 259-264

89 Ghosh A, Stasch JP, Papapetropoulos A, Stuehr DJ. Nitric oxide and heat shock protein 90 activate soluble guanylate cyclase by driving rapid change in its subunit interactions and heme content. J Biol Chem, 2014, 289: 15259-15271

90 Yang Z, Philips JD, Doty RT, Giraudi P, Ostrow JD, Tiribelli C, Smith A, Abkowitz JL. Kinetics and specificity of feline leukemia virus subgroup $\mathrm{C}$ receptor (FLVCR) export function and its dependence on hemopexin. J Biol Chem, 2010, 285: 28874-28882

91 Shemin D, Rittenberg D. The utilization of glycine for the synthesis of a porphyrin. J Biol Chem, 1945, 159: 567-568

92 Wriston JC, Lack L, Shemin D. The mechanism of porphyrin formation; further evidence on the relationship of the citric acid cycle and porphyrin formation. J Biol Chem, 1955, 215: 603-611

Open Access This article is distributed under the terms of the Creative Commons Attribution License which permits any use, distribution, and reproduction in any medium, provided the original author(s) and source are credited. 